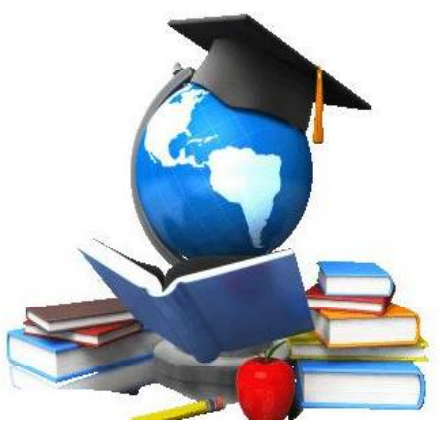

ПРОФЕСПЙНА ПІДГОТОВКА ТА ОСВІТА ДОРОСЛИХ

УДК: 378(437.1/.2): 373.67

Оксана ДЖУС, кандидат педагогічних наук, доиент, завідувач кафедри професійної освіти та інновачійних технологій ДВНЗ "Прикарпатський начіональний університет імені Василя Стефаника"

\title{
МИСТЕЦЬКИЙ КОМПОНЕНТ ЗМІСТУ ПРОФЕСІЙНОЇ ПІДГОТОВКИ ВЧИТЕЛІВ УКРАЇНСЬКОГО ВИСОКОГО ПЕДАГОГІЧНОГО ІНСТИТУТУ ІМ. М. ДРАГОМАНОВА У ПРАЗІ
}

\section{Oksana DZHUS, Ph.D (Pedagogy), Associate Professor of Pedagogy, Head of the Department of Proffesional Education and Innovative Technologies Vasyl Stefanyk Prekarpathian National University \\ ART COMPONENT OF CONTENT OF PROFESSIONAL TRAINING OF TEACHERS UKRAINIAN HIGH PEDAGOGICAL INSTITUTE OF THE NAME OF M. DRAGOMANOVA TO PRAGUE}

У статті проаналізовано місце і роль мистецьких дисциплін узмісті фахової підготовки вчителів Українського високого педагогічного інституту ім. М. Драгоманова у Празі; узагальнено відомості про мистецьку освітньо-педагогічну діяльність української діаспори та пріоритети творчої спадщини її найяскравіших представників у країнах Європи у 1920-1930 роках.

Ключові слова: еміграція, українське високе шкільництво, мистецькі дисципліни, фахова підготовка, учителі, українська діаспора, зміст освіти.

Summary. The article analyzes the place and role of artistic disciplines in the content of professional training of teachers of the Ukrainian high pedagogical institute named after them. M. Drahomanov in Prague; summarizes the information about the artistic educational and pedagogical activity of the Ukrainian diaspora and the priorities of the creative heritage of its brightest representatives in the countries

(c) О. Джус of Europe in the 1920s-1930s.

Key words: emigration, Ukrainian high school, artistic educational and pedagogical activities, artistic disciplines, vocational training, teachers, Ukrainian diaspora, content of education.

Мета: здійснити аналіз мистецьких дисциплін у змісті фахової підготовки вчителів Українського високого педагогічного інституту ім. М. Драгоманова у Празі; узагальнити відомості про мистецьку освітньо-педагогічну діяльність української діаспори та пріоритети творчої спадщини її найяскравіших представників у країнах Європи у 1920-1930 роках.

Постановка проблеми в загальному вигляді. Одним із стратегічних завдань реформування змісту освіти $є$ оптимальне поєднання класичної спадщини минулого та сучасних досягнень наукової думки, її органічний зв'язок з вітчизняною історією, культурою та педагогічним досвідом. Через те особливого значення набуває аналіз історикопедагогічної ретроспекції змісту освіти вищих навчальних закладів української діаспори, зокрема Українського високого педагогічного інституту ім. М. Драгоманова у Празі (УВПІ), за словами М. Обідного, - першої високої педагогічної української "модерної школи" у Свропі, яка"не має подібної собі... ні на заході ні на сході" [7, c. 1; 15, c. 11].

Актуальність даного дослідження зумовлена також соціально-культурним перетворенням сучасної української вищої школи, що знайшло своє відображення в пошуку та становленні нових альтернативних систем професійної підготовки, перенесенням акценту з масових педагогічних явищ на особистість. А мистецька освітньо-педагогічна діяльність західної української діаспори, репрезентована навчально-виховними інституціями та персоналіями, демонструє не лише високий рівень фахової підготовки останніх, а й конкурентоспроможність у непростих умовах чужини, що дозволяє екстраполювати їх здобутки в умовах сучасної української дійсності.

Аналіз досліджень і публікацій. Питання змісту фахової підготовки в зак- 
ладах освіти української діаспори зайшли своє втілення у дослідженнях Т. Бублик, О. Вагіної, В. Євтуха, М. Свтуха, В. Кеміня, А. Онковича, Р. Петришина та інших. Значний інформаційний матеріал із проблеми вивчення містять праці "Українська еміграція: від минувшини до сьогодення" (за ред. Б. Лановика), "Зарубіжні українці: Довідник" (кер. авт. кол. С. Лазебник), "Закордонне українство" (В. Свтух, В. Трощинський, А. Попок), 15-томник "Українці в світі" (В.Трощинський, А. Шевченко), "Українська діаспора: розселення українців у зарубіжних країнах" (Ф. Заставний), "Українці за межами УРСР (1918-1940)" (В.Трощинський, А. Шевченко, Р. Симоненко та ін.), "Українці в зарубіжному світі" (А. Шлепаков та ін.) та інше. Однак аналіз мистецьких дисциплін у змісті фахової підготовки вчителів Українського високого педагогічного інституту ім. М. Драгоманова у Празі, узагальнення відомостей про мистецьку освітньо-педагогічну діяльність української діаспори та пріоритети творчої спадщини іiї найяскравіших представників у країнах Європи у 1920-1930 pр. окремо не здійснювалися. Це й зумовило предмет нашого дослідження.

Виклад основного матеріалу дослідження. Найбільш яскравим, найпотужнішим і найавторитетнішим національним вищим навчальним закладом, який готував художні мистецькі кадри за межами рідної землі, була Українська студія пластичного мистецтва у Празі (детальніме - у статті [1]), що постала з метою "задоволення спраги" "до мистецької науки всіх молодих українських сил за кордоном України" під керівництвом Д. Антоновича. Власне, первинною іiі назвою, яка й утвердилася у свідомості діаспорного загалу, була "Українська академія образотворчого мистецтва" (чеська Академія виступила проти такого означення високої мистецької школи). Однак це не завадило об'єднати у своїх стінах когорту вчених, які "вповні задовольняли концепцію вільного розвитку талантів як основи навчального процесу Студії" [1]: професорів історії мистецтва Дмитра Антоновича, рисунка і малярства Сергія Мако, Івана Кулеця, керівників класу графіки і прикладного мистецтва Івана Мозалевського та Роберта Лісовського, інструктора граверства Едварда Кареля, Костя Стаховського (клас скульптури), Сергія Тимошенко (клас архітектури), професорів теоретичних предметів - Івана Мірчука (естетика), Степана Літова, Юрія Русова (пластична анатомія), Володимира Січинського (рисунок і перспектива), Федора Слю- саренка (класична археологія).

Високопрофесійний викладацький склад, щорічні виставки, рецензії як української, так і "чужої" преси про діяльність Студії спонукали до ії популярності не лише серед українців-емігрантів, а й чехів, росіян, білорусів, "полудневих" слов'ян, вірменів, німців, французів та інших.

Серед випускників Української студії пластичного мистецтва у Празі вирізняються Василь Касіян (уродженець Івано-Франківщини, згодом - голова правління Спілки художників УРСР, автор близько 10 тисяч робіт: гравюр, офортів, плакатів, ілюстрацій, депутат Верховної Ради УРСР чотирьох скликань); Юрій Вовк (здобув визнання як книжковий ілюстратор, портретист); Софія Зарицька (одна з кращих учениць школи Олекси Новаківського у Львові, яка отримала стипендію митрополита А. Шептицького для продовження навчання у Празі: паралельно навчалася в Українській студії пластичного мистецтва та Академії мистецтв учеській столиці), іiі майбутній чоловік Петро Омельченко (художник-графік і гравер); Оксана Лятуринська (українська художниця, скульпторка-учасниця виставок у Лондоні, Парижі, Берліні, авторка пам'ятників полеглим воякам УНР у Пардубіце (Чехія, 1932), погрудь Т. Шевченка, Т. Масарика, С. Петлюри, С. Коновальця), письменниця, поетеса і громадська діячка), Петро Холодний молодший (один 3 найвизначніших українських митців XX століття, який особливо відзначився як маляр та графік; тематика його творчості - це ікони, вітражі, мозаїки); Степан Колядинський та інші. У Студії навчалися також К. Антонович, Н. Білецька, П. Громницький, І. Іванець, М. Кричевський, Г. Мазепа, Т. Мазепа, $Є$. Норман, І.Паливода, Г. Яковлєва, Я. Фартух та багато інших [1].

Разом з тим естетична складова змісту освіти і відповідно діяльність педагогівмитців присутні й у функціонуванні Українського високого педагогічного інституту ім. М. Драгоманова (УВПІ).

Український високий педагогічний інститут ім. М. Драгоманова, який функціонував у Празі впродовж 1923-1933 pp., був високою школою 3 4-річним терміном навчання і мав такі факультети: історико-літературний (з підвідділами історії та суспільних наук і літератури й мистецтва), математично-природничий (з підвідділами математики і фізики та природничих наук) і музично-педагогічний (із 1924 р.) (з вокальним та інструментальним підвідділами) $[4, c$. 173; 6, c. 1].
Творці Українського високого педагогічного інституту ім. М.Драгоманова як "дійсної лабораторії потрібних для України педагогів-громадян" чітко усвідомлювали свою мету - підготовку кадрів культурно-політичних борців, перші лави в когорті яких мають посідати вчителі з глибокою національною свідомістю, широким ідейним розвитком таповнотою феховихзнањ [6, с. 60].

Європейський контекст функціонування першого українського педагогічного навчального закладу вищого типу за межами рідної землі закцентовано Софією Русовою - педагогом, громадською, політичною і "жіночою" діячкою, одним із співорганізаторів УВПІу праці "Нова українська культурна установа", рукопис якої сьогодні зберігається у Центральному державному архіві вищих органів влади (ЦДАВО) України в Києві. С. Русова наголошувала на реалізації представниками української політичної еміграції тих мрій, які у сфері освіти лише плекала незалежна Україна періоду визвольних змагань, зруйнованих більшовицькою владою, що перетворила "почесну постать народнього учителя" на "голу, босу, голодну людину", здатну лише працею коло землі захистити себе від голоду, переслідувана "всякими чека" і тероризовану "постійними провокаціями". Педагог стверджувала, що "Учительський Інститут тут, на еміграції, на терені вільної європейської думки може вияснити своїм слухачам нові педагогичні принципи й напрямки та випрацювати нові методи, нові форми організації найкращої суспільної національної школи на Україні, такої школи, яка б стояла на висоті сучасних педагогичних умов і задовольнила б освітні потреби нашого люду" [12, арк. 69].

I справді, проєвропейський загальноосвітній і практичний характер змісту освіти УВПІ простежується вже з початку його створення, значне місце у якому відводилося естетичній складовій. Так, серед восьми загальноінститутських кафедр в інституті функціонувала кафедра мистецтва, очолювана визначним українським архітектором, графіком, мистецтвознавцем і педагогом-практиком Володимиром Січинським.

На музично-педагогічному відділі у різний період, керованому Федором Якименком (старшим братом композитора Я. Степового, визначним представником неоромантичного напряму в музиці XX ст.) та Федором Стешком (музикознавцем, бібліографом, головою Українського музичного товариства), функціонували кафедри теорії музики і композиції; історії музики; класів фортепіа- 
но, скрипки, диригентури, вокалу ("сольового співу") [5, с. 10; 3, с. 77].

Дисципліни, які викладалися в УВПІ, поділялися на загальні (обов'язкові для всіх студентів) та спеціальні (обов'язкові тільки для студентів окремих відділів і підвідділів). Значний відсоток "загальних" курсів займали мистецькі.

Аналіз "Пляну наукових дисциплін на Українському Педагогічному Інситуті імени Михайла Драгоманова уПразі" [9] дає підстави зробити низку висновків і узагальнень. Так, на першому курсі в переліку "загальних" дисциплін (18 позицій). Разом із "Педагогікою (теорією та історією)" (6 год на тиждень у I і II семестрах), "Основою фізичного виховання у зв'язку з анатомією і фізіологією дитячого організму" (2 год відповідно), "Дошкільним і позашкільним вихованням" (4 год), "Гігієною (соціальною і шкільною)" (4 год), "Вступом до філософії" (2 год), "Психологією" (4 год), "Логікою" (2 год), "Основами права" (2 год), "Основами народного господарства" (4 год), українською (4 год.), німецькою (4 год.) та чеською (2 год.) мовами, належне місце посідали шість предметів мистецького циклу (33\%): "Історія мистецтва (всесвітнього й українського)" (6 год), "Малювання" (4 год), "Креслення (шкільне)" (2 год); "Теорія музики і співу" (4 год), "Хоровий спів" (2 год), "Гра на клавірі та скрипці" (2 год).

Зауважимо, що навчальний курс "Історія мистецтва (всесвітнього і українського)" передбачав найбільшу кількість годин серед усіх загальноосвітніх навчальних дисциплін у I семестрі - 4 год на тиждень. Навіть педагогіку і психологію слухачі УВПІ студіювали 2 год на тиждень.

На другому курсі "Історія мистецтва (всесвітнього й українського)" вивчалася у межах 4 год на тиждень у I і II семестрах (по 2 год щотижня відповідно). Такі дисципліни, як "Хоровий спів", "Гра на клавірі і скрипці" та "Малювання" вивчалися аналогічним до I курсу чином. Водночас курс "Теорія музики i співу" відсутній у навчальному плані. Натомість наявна "Історія музики (всесвітньої й української)" (по 2 год у I і II семестрах). Загалом серед 11 загальноосвітніх дисциплін на другому курсі ("Педагогічна психологія", "Позашкільна освіта", "Ручна праця (методи)", "Історія філософії", "Основи соціології", "Німецька мова") п'ять мали мистецьке спрямування (46\%).

На третьому курсі студенти УВПІ вивчали "Експериментальну педагогіку (теорію і семінар)", "Дидактику", "Шко- лознавство", "Нові форми шкільних організацій", "Етику", "Основи кооперації", "Основи сільського господарства і лісівництва", "Політичне міжнародне становище України", "Німецьку мову", а також "Музичну етнографію" (2 год на тиждень у I семестрі), "Хоровий спів" (1 год на тиждень у Iі II семестрах), "Методику малювання" (1 год. на тиждень у І семестрі). Отож предмети мистецького циклу складали $23 \%$ серед загальноосвітніх дисциплін на третьому курсі УВПІ [2; 8, арк. 8-14].

Сукупно впродовж усього терміну навчання мистецькі дисципліни серед загальноосвітніх співвідносилися як 42 до 14 , тобто становили $33 \%$.

Діяльність музично-педагогічного відділу Українського високого педагогічного інституту ім. М. Драгоманова у Празі грунтовно представлена у праці Г. Карась "Музична культура української діаспори у світовому часопросторі ХХ століття" [2]. Проте більш детальнішого аналізу потребує окреслення змісту освіти цього структурного підрозділу УВПІ. Так, у 1933 р. мистецькі дисципліни поділялися на загальнообов'язкові, загальномузичні і спеціальні. Загальномузичні дисципліни розподілялися таким чином: на кафедрі теорії музики і композиції читалися теорія музики (основи музики (I-III курси), інструментознавство (II курс), контрапункт, наука про музичні форми, акомпанемент та читання (III-IV курси), композиція (довільно); на кафедрі історії музики - історія зарубіжної музики (IIV курси), історія української музики (IIII курси), історія чеської музики (II курс), музична й загальна естетика (II курс), музична етнографія (III курс), музична педагогіка, дидактика й обов'язкове фортепіано та інтонація (I-III курси), література сольного співу (IV курс).

До спеціальних предметів належали практичні вправи (за вибором відповідно до фаху) з хорового співу та диригентури, сольного співу, спеціального фортепіано, скрипки. Окрім цього, для кожного фаху викладалися його методика i дидактика; для студентів класу співу (хорового і сольного) - теорія співу; а для студентів класу хорового співу - супровід та читання партитур. Практичні вправи включали вправи в диригуванні, сольному співі, грі на фортепіано та скрипці; відвідування концертів та музично-театральних вистав 3 поданням звітів (письмових та усних) проці відвідини; письмові реферати та дискусії на семінарах; участь в інститутському хорі та читанні лекцій в українській гімназіїбазі практики УВПІ та її структурному підрозділі [2, с. 676; 16, арк. 134-135].

Викладання таких дисциплін забезпечували фахівці високого професійного рівня. Упродовж 1923-1933 рр. академічний персонал УВПІ був представлений Володимиром Січинським (доц. мистецтва), Людмилою Красковською (асистент історії мистецтва), уже згадуваними Федором Стешком (в. о. доцента історії музики), Федором Якименком (проф. теорії музики і композиції), педагогом, диригентом, доктором музикознавства, композитором, музичним критиком, багаторічним директором Вищого музичного інституту ім. М. Лисенка у Львові Василем Барвінським (професор теорії музики і композиції), відомим композитором, піаністом, доктором філософії, згодом - викладачем Вищого музичного інституту ім. М. Лисенка у Львові Нестором Нижанківським (в. о. доцента теорії музики та композиції), субдиригентом капели О. Кошиця й учителем М. Колесси Платонідою Щуровською-Россіневич (викладач хорових дисциплін і фортепіано), а також Вірою Березовською (лектор "клавіру" - фортепіано), В'ячеславом Вагнером (лектор теорії музики і композиції), Ніною Дяченковою-Гордаш (лектор "солоспіву"), Олександром Кісяківим (лектор скрипки), Дмитром Левитським і Любов'ю Ліндфорс (лектори "солоспіву"), Зиновієм Лиско (лектор теорії музики й композиціi), Дмитром Равичем (історія музики) та ін. [3, с. 175-176].

Фахова діяльність викладачів мистецьких дисциплін знайшла втілення у видавничій продукції товариства "Сіяч", яке діяло при УВПІ, та Українському видавничому фонді у Празі. Так, упродовж 1924-1927 рр. вийшли друком праці В.Січинського "Архітектура старокнязівської доби" та Ф. Якименка "Практичний курс науки гармоніï" [4, c. 177]. У наукових збірниках "Праці Українського Високого Педагогічного Інституту ім. Михайла Драгоманова у Празі" також вміщені мистецькі студії. Зокрема, у II томі "Праць" за 1934 р. були опубліковані дослідження В.Січинського ("Гравер Олександер Тарасевич (мистецька діяльність у рр. 1672-1720)") та Ф. Стешка ("Ян Прач - один із перших збирачів та гармонізаторів укр. народніх мельодій") [10].

Наукові пошуки викладачів репрезентувалися й на різного роду зібраннях. Так, на Другому Українському науковому з'їді у Празі відома піаністка, музичний критик і педагог УВПІ Софія Дністрянська оприлюднила доповідь "Національні елементи у фортепіанній музиці останніх десятиліть". 
За весь час існування інституту до липня 1933 р. повний курс навчання прослухали 178 осіб ("дійсних студентів"). Серед дипломних робіт студентів заслуговують на увагу дослідження С. Масляка - "Музична драма Ріхарда Вагнера", П. Маценка - "35 концертів Д. Бортнянського", Г. Мельника - "Музична граматика М. Дилецького по редакції С. В. Смоленського", І. Рябіва - "Збирання та класифікація народних пісень", Д. Шиманського - "Хори на Україні до XVIII ст.", А. Яковенка "Вплив музики на людину". Частина 3 них продовжила наукову працю, захистивши докторські дисертації: П. Маценко ("Склад та технічна будова мелодій Київського розспіву в Почаївському Ірмолої 1775"), С. Масляк ("Джаз на тлі сучасності"), Д. Равич ("Українська пісня: історичний огляд її розвитку"), А. Яковенко ("Музика до "Наталки-Полтави") [2, с. 676; 7$]$.

Зауважимо, що науковим керівником докторської праці Павла Маценка (18971991) - згодом музикознавця, педагога, хорового диригента, композитора, членкореспондента УВАН був Ф. Стешко, а захищена вона була у Відні 1932 року. За ствердженням Л. Обух, це була перша робота в українському музикознавстві з даної проблематики [8, c. 72].

Серед випускників УВПІ, котрі прославили його в музично-виконавській сфері, варто назвати концертно-камерного співака (баритон) Олександра Самойловича та оперного і концертно-камерного співака (лірико-драматичний тенор) Василя Тисяка. Наукові роботи 3 музикознавства захистили Олена Шовгенів-Теліга, уже згадувані Д. Равич, А. Яковенко, С. Масляк, П. Маценко.

Окремо варто зупинитися на постаті Володимира Січинського - багаторічного завідувача кафедри мистецтва Українського високого педагогічного інституту в Празі. Упродовж 1924-1933 рр. він читав лекції і провадив практичні заняття з історії всесвітнього й українського мистецтва, історії українського друкарства і граверства, слов'янської та української палеографії, історичної географії й інших навчальних предметів. У позанавчальний час керував тематичними гуртками, проводив екскурсії пам'ятними місцями, відвідував з учнями художні виставки. Чимало часу приділяв виховній роботі з молоддю і часто виступав у періодиці зі статтями, наприклад, "Мистецтво як засіб національного виховання", "Завдання мистецького виховання в українській школі". У них порушувались проблеми підготовки якісних навчальних підручників для української освіти в еміграції з мистецтвознавства та вдосконалення форм естетичного виховання молоді [14]. Викладацьку діяльність у 1924-1927 pp. В. Січинський поєднував із власним професійним зростанням - був слухачем філософського факультету Українського вільного університету у Празі і паралельно слухав лекції з мистецтвознавства в чеському Карловому університеті, студіював у професорів Д. Дорошенка, Д. Антоновича, В. Біднова, В. Щербаківського та інших відомих педагогів, істориків і мистецтвознавців. Результатом цієї роботи став успішний захист 1927 року в Українському вільному університеті дисертації на здобуття наукового ступеня доктора філософії. Того ж року В. Січинський представив до габілітації працю "Архітектура в стародруках" і після іiї рецензування Д. Антоновичем був удостоєний звання приват-доцента кафедри всесвітнього та українського мистецтва Українського високого педагогічного інституту [17].

Інформацію про художні мистецькі дисципліни, які студіювали студенти УВПІ, знаходимо у "Звіт із діяльності кафедри історії мистецтва в УПІД у Празі за рр. 1923-1932" В. Січинського. Так, "виклади" з історії мистецтва відбувалися у такій послідовності:

а) лекції з історії всесвітнього й українського мистецтва (див. "Програм викладів історії всесвітнього мистецтва, читаних лєкт. В. Січинським в Українському Педагогічному Інституті ім. М. Драгоманова в Празі в рр. 1923-1926" [11]); української палеографії; історії українського друкарства і граверства; історії новітнього українського мистецтва ("необов'язкові" курси-факультативи);

б) семінарські заняття, вислідом яких було оприлюднення та підготовка рукописів девяти рефератів: Л. Красковська ("Порівнюючі студії архітектур України, Білорусі, Новгорода і ПсковськоВолодимирських країв старокнязівської доби"); М. Калинець ("Українське бароко і бароко Центральної Европи"); C. Нагірна ("Офортні портрети Т. Шевченка"); С. Шлендикова ("Погляди Т. Шевченка на значіння граверства"); I. Рудковський ("Ренесансові будови на Ринку у Львові"); В. Дуброва ("Портретна" мозаїка старокнязівської доби на Україні") та ін.;

в) екскурсії;

г) сім дипломних робіт, рекомендованих до друку: М. Битинський "Схід і Захід в мальовилах Богородчанського іконостасу"; Л. Красковська "Архітектура України, Білої Руси, Новгорода і
Псковсько-Володимирських країв старокнязівської доби"; І. Рудковський "Італійські майстри у Львові в XVI XVII ст."; В. Діброва "Мозаїка XI століття на Україні й Візантії"; М. Шляхтиченко "Трьохдільні муровані будови на Україні в добу готики" тощо;

д) докторські дисертації Л. Красковської ("Західні форми у візантійській архітектурі X-XIII ст. східних слов'ян") та М. Обідного ("Українська хата в порівнянні з хатами західних слов'ян"), захищені "визначно" та рекомендовані до друку [13, арк. 61-62].

Зауважимо, що учні В. Січинського залишили вагомий слід в історії України. Зокрема, Микола Битинський - український геральдист, фалерист, поет, прозаїк, публіцист, вексилолог, мистецтвознавець, дослідник і розробник емблематики та уніформології, автор двох нагород Української Народної Республіки (УНР) - Хреста Симона Петлюри та Воєнного хреста, автор низки досліджень 3 названих дисциплін, як графік створив чимало мистецьких творів, залишив по собі малярські роботи, книжкові ілюстрації, ікони, працював на педагогічній ниві) та Микола Обідний - етнограф, письменник, співзасновник Етнографічного товариства Підкарпатської Русі, сотник армії УНР, начальник Головного військово-історичного музею-архіву при Генеральному штабі військ УНР у м. Празі.

Підготовленими й опублікованими В. Січинським програмами, навчальними посібниками і підручниками користувалися практично всі українські освітянські заклади країн Свропи. Так, уже згадувана "Програма викладів історії всесвітнього мистецтва" (1926) для Українського високого педагогічного інституту ім. М. Драгоманова використовувалася кілька десятків років і в інших вищих навчальних закладах Праги, що зумовило ï перевидання 1936 року 3 певними доопрацюваннями і доповненнями автора. Для реалізації розробленої "Програми" у 1925 р. В. Січинський видав для потреб Українського високого педагогічного інституту ім. Михайла Драгоманова, Українського вільного університету та інших закладів освіти навчальний посібник "Конспект історії всесвітнього мистецтва. Ч. І. До Ренесанcy".

Висновки та перспективи подальших досліджень. Підсумовуючи означене вище, мистецькі дисципліни посідали важливе місце у змісті підготовки вчителів Українського високого педагогічного інституту ім. М. Драгоманова, а їхні викладачі забезпечили належний теоре- 
тико-методичний рівень викладання. Позитивні теоретичні надбання та практика підготовки фахівців для потреб української школи 1920-х - 1930-х рр., зокрема у сфері викладання мистецьких дисциплін, можуть бути використана і в сучасних умовах.

\section{ЛІТЕРАТУРА}

1. Джус О. В. Професійна підготовка молоді в Українській студії пластичного мистецтва у Празі. Обрії. 2015. № 1. C. $12-15$.

2. Карась Г. В. Музична культура української діаспори у світовому часопросторі XX століття: монографія. ІваноФранківськ : Тіповіт, 2012. 1164 с.

3. Мірний І. Український Високий Педагогічний Інститут ім. М. Драгоманова в Празі (1923-1933). Прага, 1934. $144 \mathrm{c}$.

4. Наріжний С. Українська еміграція. Культурна праця української еміграції між двома світовими війнами. Прага, 1942. Ч. 1.372 c.

5. Наші школи. III. Український Педагогичний Інститут ім. Михайла Драгоманова. Тризуб. Париж, 1926. Ч. 28. С. $9-12$.

6. О. Б. Український Вищий Педагогичний Інститут імени М.Драгоманова в Празі. Украӥнський студент. Прага, 1923.Ч. 3-4. С. 60-61.

7. Обідний М. Український Високий Педагогічний Інститут у Празі (3 нагоди п'ятиліття існування: 1923-1928). Діло. Львів, 1929. Ч. 4. С. 1-2.

8. Обух Л. Українська музична освіта на теренах міжвоєнної Чехословаччини. Вісник Прикарпатського університету. Івано-Франківськ: Плай, 2008. Вип. XIV. C. 69-74.

9. Плян наукових дисциплін на Українському Педагогічному Інситуті імени Михайла Драгоманова у Празі. ЦДАВО України. Ф. 3972. Оп. 1. Спр. 1. Арк. 814.

10. Праці Українського Високого Педагогічного Інституту ім. Михайла
Драгоманова у Празі: науковий збірник / за заг. ред. д-ра В. Сімовича. Прага: Вид. Укр. Високого пед. ін.-ту за допомогою М-вашкільн. народ. освіти Ч.С.Р., 1934. Т. II. Без заг. с.

11. Програм викладів історії всесвітнього мистецтва, читаних лєкт. В.Січинським в Українському Педагогічному Інституті ім. М. Драгоманова в Празі в рр. 1923-1926. Прага, 1926. 38 c.

12. Русова С. Нова українська культурна установа. ЦДАВО України. Ф. 3972. Оп. 1. Спр. 1. Арк. 69-71 а.

13. Січинський В. Звіт з діяльності кафедри історії мистецтва в УПІД в Празі за рр. 1923-1932. ЦДАВО України. Ф. 3972. Оп. 1. Спр. 57. Арк. 61-62.

14. Січинський В. Мистецтво як засіб національного виховання. Сьогодення $i$ минуле. Львів. 1939. № 1. С.47-54.

15. Український Педагогічний Інститут у Празі. Нова хата. Львів. 1929. Ч. 11. C. 11

16. ЦДАВО України. Ф. 3972. Оп. 1. Спр. 222. Арк. 134-135.

17. ШДІА України у Львові. Ф. 328. Оп. 1. Спр. 104. Арк. 21.

\section{REFERENS}

1. Dzhus O. V. Professional training of youth in the Ukrainian studio of plastic art in Prague. Horizons: 2015. №. 1. P. 12-15.

2. Karas G.V. Musical culture of the Ukrainian diaspora in the world time period of the twentieth century: a monograph. Ivano-Frankivsk: Titipot, 2012. 1164 p.

3. Mirnyi I. Ukrainian High Pedagogical Institute. M. Drahomanov in Prague (19231933). Prague, 1934. 144 p.

4. Naryzhny S. Ukrainian emigration: Cultural work of Ukrainian emigration between two world wars. Prague, 1942. Part $1.372 \mathrm{p}$.

5. Our schools. III Ukrainian Pedagogical Institute Mikhail Drahomanov Trident Paris, 1926. P. 28. P. 9-12.

6. O. B. Ukrainian High Pedagogical Institute named after M. Dragomanov in
Prague. Ukrainian student. Prague, 1923. Ch. 3-4. Pp. 60-61.

7. Lunch M. Ukrainian High Pedagogical Institute in Prague (On the occasion of the five-year existence: 19231928). Work. Lviv, 1929. №. 4. P. 1-2.

8. Obukh L. Ukrainian music education in the areas of interwar Czechoslovakia. Bulletin of the Precarpathian University. Series: "Art Studies". Ivano-Frankivsk: Play, 2008. Voice. XIV. P. 69-74.

9. Plans of scientific disciplines at the Ukrainian Pedagogical Insitute named after Mikhail Dragomanov in Prague. Central state archives of the highest authorities of Ukraine. S. 3972, d. 1, c. 1, p. 8-14.

10. Proceedings of the Ukrainian High Pedagogical Institute named after. Mykhailo Drahomanov in Prague: a scientific collection / For co. edit Dr. V. Simovich. Prague: View. Ukr High Ped. etc. with the help of the M-va school. people. Education Ch.S.R., 1934. T. II. No zag with.

11. Programs of presentations of the history of world art, read by the object. V. Sichinsky at the Ukrainian Pedagogical Institute. M. Drahomanov in Prague in the years 1923-1926. Prague, $1926.38 \mathrm{p}$.

12. Rusova S.Nova is a Ukrainian cultural institution. Central state archives of the highest authorities of Ukraine. S. 3972. D. 1. C. 1. P. 69-71 a.

13. Sichinsky V. Report on the activities of the Department of Art History in UPID in Prague for the years 1923-1932. Central state archives of the highest authorities of Ukraine. S. 3972. D. 1.C. 57. P. 61-62.

14. Sichinsky V. Art as a means of national education. Present and past. Lviv. 1939. №. 1. P. 47-54.

15. Ukrainian Pedagogical Institute in Prague. New hut. Lviv. 1929. №. 11. P. 11.

16. Central state archives of the highest authorities of Ukraine. S. 3972. D. 1. C. 222. P. 134-135.

17. Central State Historical Archive in Lviv. S. 328. D. 1. C. 104. P. 21

Стаття надійшла 17.05.2019 p. 